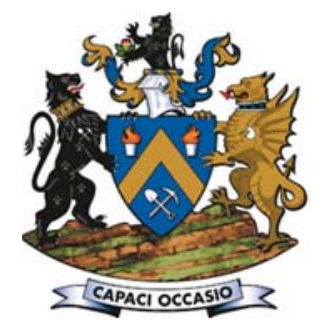

\title{
Working towards an increase in manganese ferroalloy production in South Africa - a research agenda
}

\author{
by J.D. Steenkamp*, W.G. Bam ${ }^{\dagger}$, E. Ringdalen ${ }^{\ddagger}$, \\ M. Mushwana*, S.A.C. Hockaday*, and N.A. Sithole*
}

\section{Synopsis}

Although South Africa is endowed with one of the largest land-based deposits of manganese ore, in the order of $80 \%$ of the ore mined is exported for beneficiation elsewhere. The past 15 years has seen a decline in the production of manganese ferroalloys locally due to a steep rise in the price of electricity, among other factors. As local beneficiation of South Africa's resources is a national priority, a research agenda to increase manganese ferroalloy production in South Africa was developed. Inputs were obtained from various role-players in the value chain, including local smelter operations, research institutions both local and abroad, and companies providing support to the industry. Ninety-five research opportunities were identified and grouped into twenty-one research themes. The results are reported here in the context of a review of relevant Infacon papers and Mintek reports. As implementation of such a research agenda could be done through the development of a technology roadmap, the paper concludes with an example from Norway where a roadmap was developed to increase the use of natural gas in metal production.

Keywords

research themes, manganese ferroalloy production, South Africa.

\section{Introduction}

Despite its importance in the production of steel, manganese is also considered a relatively rare metal (Reijnders, 2016). Reijnders (2016) defined relatively rare metals as:

'geochemically relatively scarce (having an upper crustal abundance $<\sim 0.025$ mass per cent)' or 'subject to national stockpiling to prevent shortages in alloy production'. Although manganese is the 12th most abundant element in the Earth's crust, with an average concentration of $0.1 \%$ (Olsen, Tangstad, and Lindstad, 2007), ores of commercial importance are geographically limited. Therefore countries, including the USA (Corathers, 2017), manage national stockpiles of ore and alloys.

In South Africa, manganese was discovered in 1907 at Black Rock and initially mined in Hout Bay near Cape Town, from where small quantities were exported in 1917 (Pienaar and Smith, 1992). Mining in the Postmasburg area started in 1922 and in the Kalahari Manganese Field (KMF), one of the largest land-based deposits of manganese ores of commercial importance (Corathers, 2017), in 1954. This natural resource has been beneficiated in the country since 1937, when high-carbon ferromanganese (HCFeMn) was produced using blast furnace technology (Basson, Curr, and Gericke, 2007). In 1942, a technology step-change occurred when a 3 MVA submerged arc furnace (SAF) was used for the first time to produce HCFeMn.

In 2016, South Africa accounted for $78 \%$ of the world's identified manganese resources and 29\% of the world's reserves (Corathers, 2017). Currently, South Africa has an installed manganese ferroalloys capacity of about 1.2 $\mathrm{Mt} / \mathrm{a}$, applying SAF technology in the production of HCFeMn and silicomanganese (SiMn) - see Table I. Medium-carbon ferromanganese (MCFeMn) is produced at two sites using converter technology.

Data provided by Mintek's Mineral Economics and Strategy Unit indicated that until 2001, in the order of 50\% of manganese ore produced was smelted locally. Since then, local sales have remained stagnant but export sales have increased to such an extent that $84 \%$ of the ore produced in 2014 was exported. In a report available in the public domain (Directorate: Mineral Economics, 2016), the Department of Mineral Resources of South Africa reported this amount at $70 \%$ in 2014. The increase in ore exports is mainly due to increased production capacity for manganese ferroalloys in Asia and Oceania, specifically China (Steenkamp and Basson, 2013).

Due to the lucrative export market for ore, the steep increase in electricity tariffs, and the price of manganese ferroalloys remaining fairly constant (van Zyl, Bam, and Steenkamp,

\footnotetext{
* Mintek, South Africa.

+ Stellenbosch University, South Africa.

‡ SINTEF, Norway.

(c) The Southern African Institute of Mining and Metallurgy, 2018. ISSN 2225-6253. This paper was first presented at the INFACON XV: International Ferro-Alloys Congress, 25-28 February 2018, Century City Conference Centre and Hotel, Cape Town, South Africa
} 


\section{Working towards an increase in manganese ferroalloy production in South Africa}

\begin{tabular}{|c|c|c|c|}
\hline \multicolumn{4}{|c|}{$\begin{array}{l}\text { Table I } \\
\text { Installed capacity for manganese ferroalloys in } \\
\text { South Africa }\end{array}$} \\
\hline $\begin{array}{l}\text { Operating } \\
\text { company }\end{array}$ & Commodity & $\begin{array}{c}\text { Production } \\
\text { rate (kt/a) }\end{array}$ & $\begin{array}{c}\text { MVA } \\
\text { installed }\end{array}$ \\
\hline $\begin{array}{l}\text { Metalloys } \\
\text { Assmang Cato Ridge } \\
\text { Assmang Machadodorp } \\
\text { Transalloys } \\
\text { Mogale** } \\
\text { TOTAL }\end{array}$ & $\begin{array}{l}\text { HCFeMn } \\
\text { HCFeMn } \\
\text { HCFeMn } \\
\text { SiMn } \\
\text { SiMn }\end{array}$ & $\begin{array}{c}480 \\
240 \\
270 \\
180 \\
40 \\
1210\end{array}$ & $\begin{array}{l}312 \\
116 \\
132 \\
161 \\
40 \\
761\end{array}$ \\
\hline
\end{tabular}

* On care and maintenance

** Currently converted to $\mathrm{FeCr}$ production

2016; van Zyl, 2017), the production and sales of manganese ferroalloys in South Africa have been declining, resulting in job losses among other impacts. Only around $40 \%$ of the installed capacity listed in Table I is currently in use (personal communications with various plant personnel, 2017). In a country with an official unemployment rate of 25.3\% in 2015 (Stats SA, 2016), there is a need for the development of a national research agenda (Phaal, Farrukh, and Probert, 2004) to increase beneficiation of manganese ore in South Africa. The aim of the study presented here was to define such a research agenda from a multi-organizational perspective (Phaal, Farrukh, and Probert, 2004) and look at not only supporting existing operations, but also working towards step-change technologies.

\section{Methodology}

The term value chain can be used to describe the full range of activities performed to bring a product from its conception to end-use and beyond (Gereffi and Fernandez-Stark, 2011). Such maps can be useful to determine the interdependencies between various products and processes. A recent version of the manganese value chain map was described by van Zyl (2017). The section applicable to this study is indicated in Figure 1 and consists of three stages.

> Stage A-Geology, mining, and beneficiation: The manganese orebody under investigation was limited to the KMF, based in the Hotazel area of the Northern Cape Province of South Africa. Products produced in Stage A include lumpy ore and fine ore upgraded in the form of sinter, to meet the chemical, phase chemical, and physical (size) requirements of SAF technology applications in South Africa. Waste streams were streams that did not meet these criteria.

- Stage B-Reduction: The reduction step consisted of the production of SiMn or HCFeMn using SAF technology with the products from Stage A being the main sources of manganese. Waste streams generated included slag, dust and off-gas, and unsaleable metallic fines.

- Stage C-Refining: The refining step consisted of the production of MCFeMn using converter technology, the HCFeMn from Stage B being the main source of manganese. As with Stage B, waste streams generated included slag, dust and off-gas, and unsaleable metallic fines.

With the value chain defined in Figure 1 as a basis, the method followed to identify and evaluate the research opportunities and themes is summarized in Figure 2.

> Phase 1-Six categories were identified using a process broadly similar to that proposed by Jabareen (2008) and depended on four main sources: (i) the shareholder performance agreement between Mintek and the South African government for 2015, (ii) the Mintek Pyrometallurgy Research Roadmap for 2015, (iii) an overview of the manganese ferroalloy industry by Steenkamp and Basson (2013), and (iv) a follow-up study by van Zyl (2017). The research categories are presented in Table II. Knowledge leaders from South Africa, Norway, and Namibia, were identified in the fields of operations (13), research and development (26), and support (13). They were invited to participate in a workshop included in the programme of the Second School on Manganese Ferro-alloy Production hosted in South Africa on 27 and 28 June 2016.

> Phase 2-The First School on Manganese Ferro-alloy Production was hosted in 2012 in South Africa in order to support local smelters and foster collaboration between researchers in the field based in South Africa and Norway. The intention of the Second School on Manganese Ferro-alloy Production was to build on

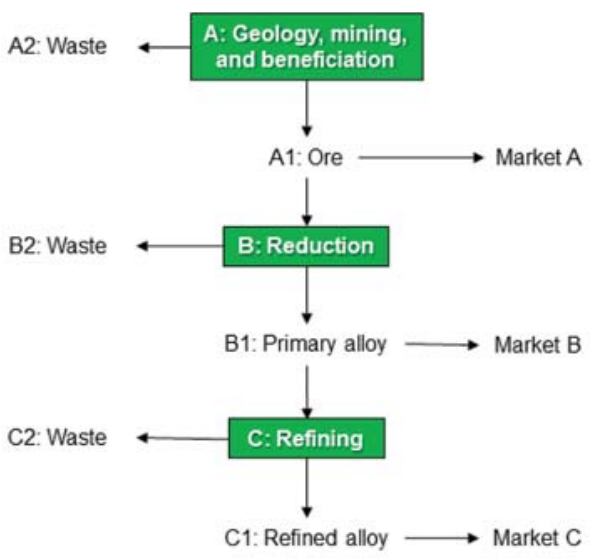

Figure 1-Various stages in the value chain map under investigation

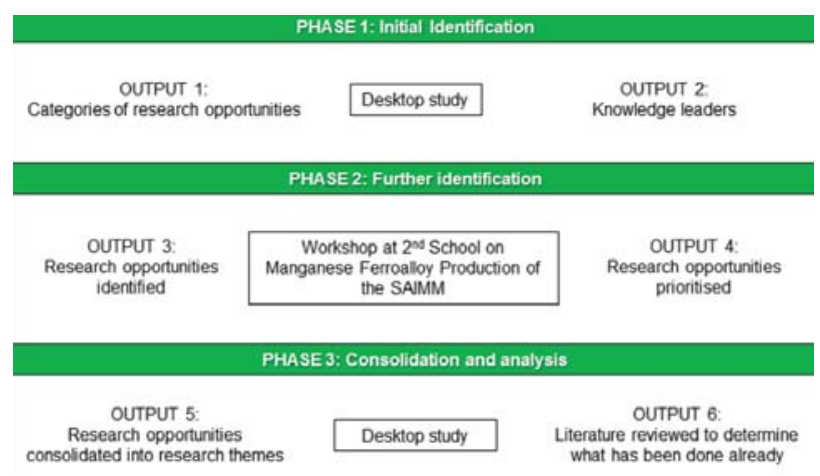

Figure 2-Research phases followed in identifying a research agenda to increase manganese ferro-alloy production in South Africa 


\section{Working towards an increase in manganese ferroalloy production in South Africa}

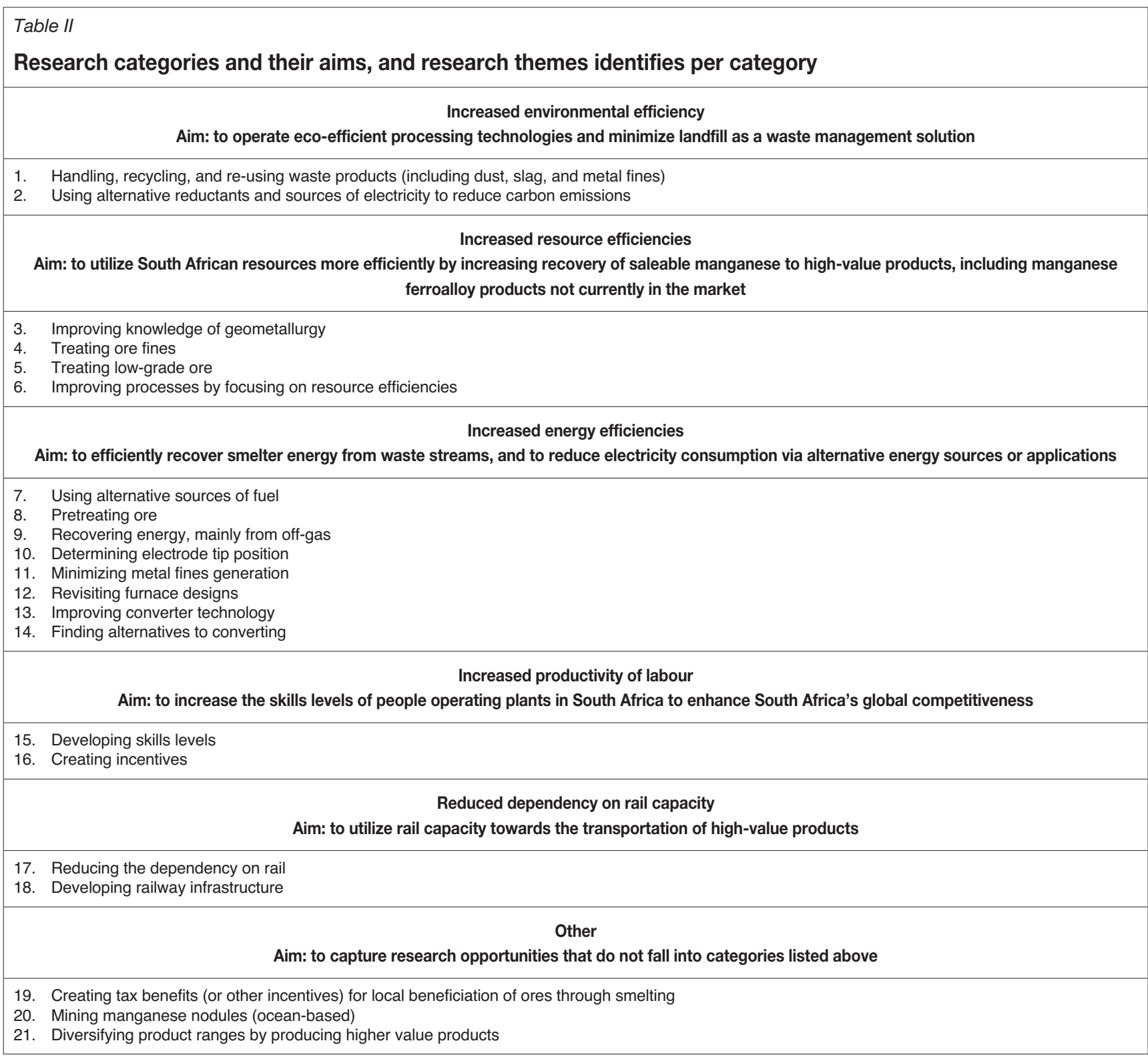

these collaborations by hosting a workshop for the collaborative identification of research opportunities. When introducing the workshop towards the end of the series of lectures, all delegates were invited to participate. The school was attended by 71 delegates and the workshop by about 36 participants (completion of the attendance register was voluntary). Approximately $50 \%$ of the workshop participants were the invited knowledge leaders.

The facilitation methodology followed at the workshop is summarized in Figure 3 and described as follows:

1. Six workshop stations were set up. These consisted of (i) one station per value chain stage focusing on how existing technology applied at operations could be improved in each of the research opportunity categories, and (ii) one station per value chain stage focusing on how step-change technologies could contribute to the competitiveness of the South African manganese industry.
2. Workshop participants divided themselves into six groups. These groups were rotated amongst the six stations for ten minutes at a time. This enabled all workshop participants to contribute to each of the six stations. The participants were tasked with (i) identifying the key research opportunities and (ii) identifying where these opportunities fit in the categories (if at all).

3. The groups from the same value chain stages were combined and given twenty minutes to determine a prioritized list of research opportunities for each value chain stage.

4. Thereafter, all the knowledge leaders were reconvened and tasked with agreeing on the overall priorities that would best support the long-term competitiveness of the manganese industry in South Africa, for the entire value chain.

> Phase 3-In total, 95 research opportunities were identified, $50 \%$ in support of existing operations and 


\section{Working towards an increase in manganese ferroalloy production in South Africa}

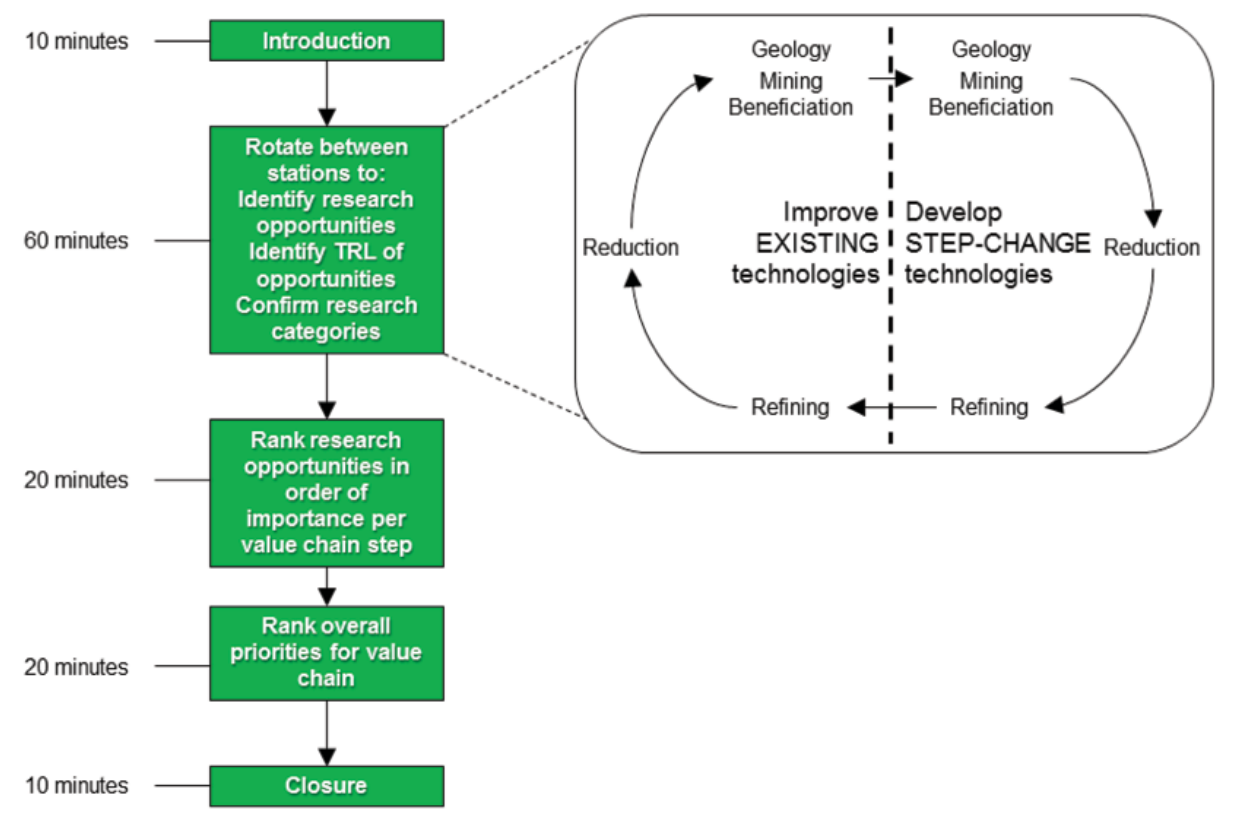

Figure 3-Workshop methodology

$50 \%$ to develop step-change technologies. The research opportunities were revised to ensure there was no duplication or errors, and summarized into tables. The research opportunities were then consolidated into 21 research themes, which are presented in Table II. A more complete data-set is available online at http://www.pyrometallurgy.co.za/InfaconXV/9999Steenkamp-Tables.docx

To obtain an understanding of the extent to which these research themes and opportunities have been investigated in South Africa and abroad, a review of relevant Infacon papers and Mintek reports was conducted. The results of the review are reported in the next section. Also included in the review are relevant papers published elsewhere that formed part of the existing knowledge base of the authors.

\section{Literature review}

\section{Environmental efficiency}

\section{Handling, recycling, and re-using waste products}

Waste products from manganese ferroalloy production are dust (formed in sinter belts and in SAFs), slag, and metal fines. Environmental concerns include problems experienced in the short term, i.e. exposure of employees and communities to dust, and as well as the long term, i.e. disposal on waste dumps where prevention of groundwater contamination by manganese leached from the waste products is a major challenge.

Dust suppression during sintering is a key area of concern. To address the problem, a two-stage system was implemented in which the baghouse system on the cooling section was separate from the one on the sintering section. The latter was considered a novelty (Osypenko et al., 2015). Cleaning of off-gas emitted by SAFs results in two types of waste products: dry dust in bag filter off-gas cleaning systems and sludge in wet scrubber systems. In both instances, dust is disposed of as landfill. To minimize air pollution from these landfill sites, bag plant dust is agglomerated (Davey, 2004; and also according to work done at Mintek in 1987). Not only can the dust then be disposed of at landfill sites, but agglomeration techniques also allow for recycling of dust, together with metal fines, to SAFs (Davey, 2004). Alternative treatment methods proposed for sludge handling include drying and sintering to fume the zinc present in the sludge (Hamano et al., 2010) or smelting in a centralized facility to produce high-MnO slag (to be recycled as feedstock to a SiMn smelter) together with a small amount of alloy rich in phosphorus and boron, and fume containing $>99 \%$ of the zinc and $>90 \%$ of the alkalis (Gaal, Tangstad, and Ravary, 2010). Melting of metal fines in a separate DC arc furnace was also investigated at Mintek in the 1980s, and found to be technically feasible. Converter dust produced during the refining of HCFeMn contains significant amounts of MnO (Lee et al., 2010). Applications as soft ferrite, lubricant in oil drilling, and pigment for refractory, were considered. An aluminothermic reduction process was also developed to produce an alloy containing > 90\% Mn at $86 \%$ Mn recovery (Lee et al., 2010).

When it meets environmental requirements, slag is typically used as road base or as aggregate (Gaal, Tangstad, and Ravary, 2010) but in South Africa slag produced in HCFeMn production is disposed of as landfill. Manganese can be recovered from these slags by pyrometallurgical or hydrometallurgical means. Metallothermic reduction processes are based on $\mathrm{FeSi}, \mathrm{Si}, \mathrm{Al}$, or pig iron as reductants (Banda and Lagendijk, 2017a, 2017b; Dashevskiy et al., 2013; Kamata, Kuzi, and Tsujimura, 1992), and sulphuric acid is used to leach manganese (Groot et al., 2013; Kazadi et al., 2013, 2016; Sancho et al., 2015). In both cases, it is not only the recovery of manganese that is of economic interest, but also the production of high-value byproducts that can be used as cement extenders. 


\section{Working towards an increase in manganese ferroalloy production in South Africa}

\section{Using alternative reductants and sources of electricity to reduce carbon emissions}

$\mathrm{CO}_{2}$ emissions are harmful to the environment. As they use carbothermic reduction processes (with coke, anthracite, and coal as reductants), manganese ferroalloy producers are also producers of $\mathrm{CO}_{2}$. In South Africa, the problem is exacerbated by the fact that electricity is produced mainly at coal-fired power stations. Charcoal (Monsen, Tangstad, and Midtgaar, 2004; Monsen et al., 2007) or other biofuels (Zhao, Zhu, and Cheng, 2010) from renewable sources could potentially be used as reductants in smelting, to reduce carbon emissions. Alternatively, hydrogen gas $\left(\mathrm{H}_{2}\right)$ could be utilized in the prereduction of manganese ores (Kononov, Ostrovski, and Ganguly, 2007), with methane as potential source of $\mathrm{H}_{2}$ and $\mathrm{CO}$ through the cracking of $\mathrm{CH}_{4}$ (Anacleto, Ostrovski, and Ganguly, 2004; Bhalla and Eric, 2015; Ostrovski, Anacleto, and Ganguly, 2004). Potential green technologies for power generation include photovoltaic (PV) plants, wind power, concentrated solar power (CSP) plants, and tidal energy, and for transportation, electrical or fuel-cell-driven equipment. The application of CSP in the preheating and sintering of manganese ores is currently being investigated (Hockaday, Dinter and Harms 2016; Hockaday et al., 2017).

\section{Resource efficiency}

\section{Improving knowledge of geometallurgy}

Geometallurgy is the linking of geology, mining, and metallurgy, and understanding the implications of these links (Chetty, 2008). In smelter operations it leads to improved understanding of input materials and their effects on smelter operations. In the SAF, manganese ore is reduced in the solid state by $\mathrm{CO}$ gas to $\mathrm{MnO}$ and $\mathrm{Fe}$, and in the liquid state in the coke bed to $\mathrm{Mn}$ and $\mathrm{Si}$. If the ore reaches $800^{\circ} \mathrm{C}$ without being fully reduced to $\mathrm{MnO}$ and $\mathrm{Fe}$, the $\mathrm{CO}_{2}$ produced in the solidstate reduction reactions will increase the reductant and energy consumption due to the endothermic Boudourd reaction (Tangstad et al., 2004; Visser et al., 2013). Therefore, for solid-state reactions ore properties of importance are the oxidation state (Featherstone, 1974; Chetty and Gutzmer, 2008), reducibility (Kumar, Ranganathan, and Sinha, 2007), and more specifically CO gas reactivity (Tangstad et al., 2001; Pochart et al., 2007; Visser et al., 2013). For liquid-state reactions, electrical conductivity (Miyauchi, Mochida, M., and Fuchi2001; Miyauchi et al., 2004) and melting properties (Ringdalen, Gaal, and Ostrovski, 2010; Visser et al., 2013) are important. In terms of other raw materials, the $\mathrm{CO}$ and slag reactivities of the carbon materials are of importance (Grishchenko et al., 2015; Monsen, Tangstad, and Midtgaar, 2004; Pistorius, 2002; Safarian et al., 2006, 2008; Safarian and Kolbeinsen, 2008), as is the dissolution rate of the quartz into slag (Maroufi et al., 2015).

\section{Treatment of ore fines}

As SAF technology typically requires a burden that is gaspermeable, particles less than $6 \mathrm{~mm}$ in size are screened out either at the mine or at the smelter. These ore particles still meet the chemical requirements for smelting. To agglomerate these particles, sinter-strand technology with coke breeze as fuel source is applied on the industrial scale (Pienaar and Smith, 1992). Sintering also results in savings in transport cost per manganese unit, and decreased energy consumption in the SAF. Baghouse dust, scrubber sludge, quartz fines, HCFeMn slag fines, coke fines, and alloy fines could also be added to the sinter mix if sintering occurs at the smelter (Crawford et al., 1995; Malan et al., 2004). Prereduction of ore fines in a fluidized bed reactor (Crawford et al., 1995) with subsequent smelting in a DC arc furnace has been tested at pilot scale. Technologies incorporating a dual energy source consisting of an inductor and oxygen-enriched combustion zone have been evaluated up to demonstration scale (Coetsee et al., 2015).

\section{Treatment of low-grade ore}

Today, Mamatwan-type ore is not only beneficiated locally but also exported for processing overseas. Ironically, in the 1970s Mamatwan-type ore was deemed unsuitable for processing in a SAF due to the high carbonate contents (Featherstone, 1974) but SAF operators adjusted their practices to allow for higher carbonate contents. Managing the $\mathrm{Mn} / \mathrm{Fe}$ ratio of the ores from the Northern Cape Province remains a challenge and a significant amount of ore with low manganese content is available. To increase the $\mathrm{Mn} / \mathrm{Fe}$ ratio, wet or dry magnetic separation of fine ore with subsequent agglomeration of the nonmagnetic fraction through sintering or briquetting could be applied (Kutsin et al., 2015). Prior to magnetic separation, a magnetizing roasting step, with or without subsequent milling, could improve separation (Ghorpade, 1995; Kivinen, Krogerus, and Daavittila, 2010; Samuratov, Baisanov, and Tolymbekov, 2010 and also at Mintek in 1981 and 1987). Alternatively, pig iron and high, MnO slag could be produced in a blast furnace and the slag further processed in a SAF (Ghorpade, 1995; Zhang, 1992).

\section{Process improvements focusing on resource efficiencies}

Proposed process improvements specifically associated with resource efficiencies included increasing the sinter/ore ratio into the SAF, combining silicon carbide ( $\mathrm{SiC}$ ) and carbon (C) as reductants in SiMn production, and removal of alkalis (including potassium) prior to smelting. No references on such applications were found during the review.

\section{Energy efficiency}

\section{Alternative sources of fuel}

Apart from the green technologies already listed as alternative sources of energy, shaft furnace (Suzuki and Masukawa, 1992) or blast furnace (Basson, Curr, and Gericke, 2007; Featherstone, 1974) technology could also be considered as these furnaces utilize the combustion of coke and/or pulverized coal in order to meet the process energy requirement. On the other hand, switching to fossil fuel-fired furnaces will increase a plant's $\mathrm{CO}_{2}$ output and reduce its environmental efficiency. In the South African context, where electricity is produced mainly in coal-fired power stations, power generation should be taken into account when studying the environmental efficiency of any alternative. A desktop study is currently underway at Mintek to evaluate 


\section{Working towards an increase in manganese ferroalloy production in South Africa}

the feasibility of COREX and FINEX technology for HCFeMn production (Sithole, Bam, and Steenkamp, 2018).

\section{Pretreatment of ore}

Preheating, precalcination, or prereduction, particularly of carbonate-rich manganese ores, has the potential to reduce the electrical energy requirement by 25 to $35 \%$ (Kalenga Xiaowei, and Tangstad, 2013; Tangstad, Ichihara, and Ringdalen, 2015). Sintering is an example of a calcination process in which the carbonate content of ore is lowered (Pienaar and Smith, 1992). On the industrial scale, a rotary kiln has been installed upstream from a SAF for prereduction of the ore (Tangstad Ichihara, and Ringdalen, 2015). Leaching of carbonate-rich ores to reduce the carbonate content has also been proposed (Featherstone, 1974).

\section{Energy recovery from off-gas}

Many SAFs operated in South Africa are of open furnace designs where the off-gas, slag, and alloy all contains latent heat that could be recovered and used elsewhere.

Furthermore, by converting SAFs to closed designs one could potentially reduce energy losses and allow for the utilization of carbon monoxide (CO) in off-gas for preheating and/or prereduction, or generation of electricity (Ghorpade, 1995; Hunsbedt et al., 2007; Kitamura, 1983).

\section{Electrode tip position determination}

Coke bed management is important in SAF operations (Lee and Tangstad, 2010). Development of technology to determine the electrode tip position would be useful. Development of a thermodynamic and/or electrical model to measure the level of the coke bed has been found to be useful (Yamamoto et al., 1986).

\section{Minimizing metal fines generation}

The market for manganese ferroalloy fines is basically nonexistent as steel producers have specific size requirements for products that meet the requirements of their material handling and feeding systems, as well as process conditions. In SiMn production, casting alloy in a doublestrand casting machine resulted in much less fines generated compared to layer casting (Bezemer, 1995).

\section{Revisiting furnace designs}

Revisiting furnace designs and dimensions (Nishi, Saitoh, and Teguri, 2007; Swamy et al., 2001; Bisaka, Griesel, and Bouwer, 2004), including improved refractory design for decreased wear and improved efficiencies (O'Shaughnessy and Le Roux, 2015; Steenkamp, 2014; Steenkamp, Pistorius, and Tangstad, 2015a, 2015b; 2015c), could be useful from an energy efficiency perspective, as would the development of reliable measurement techniques for temperature, refractory wear (Sadri, Gebski, and Shameli, 2010), and water leak detection (Eidem, Egeland, and Baumann, 2013). As DC technology could potentially allow for improved energy efficiency by decoupling power input from coke bed resistivity, revisiting application of the technology in different configurations could also be useful (Jones, Barcza, and Curr, 1993) and work in this regard was been undertaken at Mintek in 2016.

\section{Improving converter technology}

As with the SAFs, improving existing converter technology (Burger and Masukawa, 2004; Cowx et al., 2015) by improving energy efficiency or developing a thermodynamic model (Nell and Nolet, 2010) to describe converter refining of HCFeMn would be useful in attempts at improving operational efficiencies.

\section{Alternatives to converting}

Alternatives to converting that were proposed included refining liquid alloy straight from tapping and utilizing argon-oxygen degasser (AOD) and vacuum-oxygen degasser (VOD) type processes applied in steelmaking in manganese ferroalloy production. No references to any of these applications were found in the literature - the latter being technically not feasible due to the high vapour pressure of manganese - but alternative methods were identified. These included solid-state decarburization of carbon-rich manganese carbide powders in a flowing stream of carbon dioxide (Bhonde and Angal, 2004), refining of SiMn in a two-stage process consisting of a smelting step in an electric arc furnace followed by treatment in a shaking ladle (Jinhua and Zhizhong, 1992), and silicothermic reduction of manganese-bearing slags used to produce MCFeMn (Channon and See, 1977). The latter technique was applied on an industrial scale in South Africa (Bezemer, 1995), but the facility is currently decommissioned. In Japan (Yamamoto et al., 1986), a similar process was replaced by converter technology.

\section{Productivity of labour}

The research topics listed in this section contain only a summary of the research opportunities identified in the workshop. A literature study on any of the topics or themes falls beyond the scope of this document.

\section{Developing skills levels}

In terms of skills development, it was proposed that local training centres were to be established, teaching not only technical skills but also transferring knowledge on the value chain, basic economics, and basic metallurgy. Furthermore, employees should be given the opportunity to use current plant problems as potential topics for postgraduate studies, one such potential topic being an evaluation of the economic feasibility of the various alternative technologies listed here. As an example: in Norway, producers of ferroalloys release employees for a three-year period to study full-time towards a PhD at the Norwegian University of Science and Technology. Often, the research topic is chosen and (partially) funded by the producer. This arrangement benefits the producer through the development of new knowledge, as well as its employees. Such studies will build the capacity studies of local universities and ensure quality education for future generations.

\section{Creating incentives}

It was proposed that companies commit to educate children of employees, implement profit sharing schemes for employees, and create incentives for labour to multi-skill. In terms of 


\section{Working towards an increase in manganese ferroalloy production in South Africa}

academic support, remuneration of academics should be increased as should research funds. Discussion of this topic is beyond the scope of this paper.

\section{Dependency on rail capacity}

\section{Reducing dependency on rail}

To reduce dependency on rail capacity it was proposed that mining, pretreatment, and/or smelting processes be integrated close to the mine-site, resulting in only valueadded products being transported rather than transporting gangue together with the manganese values. Reagents used in processing should be sourced closer to the smelter. Furthermore, clustering synergistic industries, where one plant uses the products of another, would be ideal, e.g. integrating a FeMn smelter with a steel plant (Kitamura, 1983; Yamamoto et al., 1986). It was proposed that fines/slimes be transported pneumatically.

\section{Developing railway infrastructure}

Development of railway infrastructure within Africa, as well as improving railway transport security, could be useful, but discussion of this topic is beyond the scope of this paper.

\section{Other}

\section{Creating tax benefits}

Creating tax benefits (or other incentives) for local beneficiation of ores through smelting could be useful. Discussion of this topic is beyond the scope of this paper.

\section{Mining manganese nodules (ocean-based)}

Manganese nodules were leached in a laboratory-scale study to produce copper, nickel, and cobalt (Alex et al., 2007). The leach residue, being rich in $\mathrm{Mn}$ and $\mathrm{Si}$, was agglomerated and smelted in a DC furnace in combination with HCFeMn slag to produce SiMn. The economic feasibility of such a technology should be definitely be included in future studies.

\section{Diversifying product ranges by producing higher value products}

As the bulk of manganese ferroalloys are utilized in steelmaking, product ranges could be diversified by producing alloys that are more attractive to the steel industry. These include alloys that support the production of clean steel with very low levels of phosphorous, sulphur, and inclusions (Safarian and Kolbeinsen, 2013; Sjoqvist, Jonnson, and Berg, 2001) or specialized products with high levels of a desirable component ( $\mathrm{N}$ or $\mathrm{Si}$ ). Typically, all P present in the ore and reductants reports to the alloy phase (Pochart et al., 2007; Tangstad et al., 2004; Visser et al., 2013) and subsequent dephosphorization of alloy can be done using $\mathrm{BaO}-\mathrm{MnO}_{-} \mathrm{BaF}_{2}$ slag (Chaudhary, Minj, and Goel, 2007). Sulphur distribution can be influenced by the basicity and CaO content of the slag (Saridikmen, Kucukkaragoz, and Eric, 2007). Titanium can be removed from SiMn alloy by purging with nitrogen (Chu, Chen, and Zeng, 2015). The nitrogen content of LCFeMn can be increased by solid-state nitriding with a mixture of nitrogen and hydrogen gas (Ghali et al., 2010) to produce an alloy that could potentially replace nickel in stainless steel production. Low-carbon SiMn with $20-30 \%$ Si is produced by upgrading standard SiMn alloy through the addition of $\mathrm{Si}$ wastes from the ferrosilicon industry (Park et al., 2010), which not only increases the Si content of the alloy due to dissolution, but the carbon content is also reduced through the formation of SiC. Granulation of SiMn to produce a powder that can be stored in bags as raw material for electrolytic manganese production, and utilization of converter dust, rich in manganese, as alternative to electrolytic manganese were listed as ideas at the event, but no literature sources found on these topics during the review.

\section{The way forward}

Transforming ideas and proposed technologies into industrial applications that contribute to company profits and an improved society takes a long time. A roadmap is a tool that could ease the way towards implementation (Phaal, Farrukh, and Probert, 2004) and would be a useful aid in the implementation of the research agenda developed here. As a starting point, an example from Norway where a roadmap was developed to increase the use of natural gas in metal production is presented.

The Norwegian government prepared a series of roadmaps to guide the country towards reducing its $\mathrm{CO}_{2}$ emissions by 2030 and 2050, in terms of the Paris Climate Agreement. The exercise included a roadmap for the process industry (Norsk Industri, 2006). In order to break down the proposed initiatives into more specific actions, research institutes (SINTEF and NTNU) and industry together prepared a roadmap for the use of gas in metal production (Dalaker et al., 2017). The same methodology could be used for preparing a roadmap for increased manganese ferroalloy production in South Africa.

The work started by defining who the roadmap was written for and what the goals were. The two main goals were (1) to describe to the authorities the conditions and public framework needed to obtain the desired changes in industry, and (2) to give examples of potential technologies to develop. To achieve these goals, industry must be heavily involved in document preparation, and at the same time the document must be neutral and not represent specific companies. The current roadmap (Dalaker et al., 2017) was therefore prepared by the research institutes, with industry involvement from several companies through cooperation on a dedicated project and several targeted workshops. The project was funded by SINTEF, the Norwegian Research Council, and industry partners acting either as individual companies or through the Norwegian Ferroalloy Producers Research Association.

The roadmap started by contextualizing the objectives and describing their importance. Then, to demonstrate that technological solutions were available, a wide range of relevant technologies were described. Technologies with a high potential were included notwithstanding whether they would require a long time (10-20 years) to implement or whether they could be industrialized in the near future. Technology readiness levels (TRLS), derived from the European Union Commission's definitions, and environmental impact were shown for each technology.

The section describing the need for public framework conditions, addressed mainly to the authorities, was divided 


\section{Working towards an increase in manganese ferroalloy production in South Africa}

into two sections and described (1) prerequisites for technology development and (2) prerequisites for industrial use. Education and high competence in both academia and industry are required for technology development. Competence within specific areas described in the roadmap, as well as in general education, is needed. A good research infrastructure and a system for public funding of long-term research projects are also important. Industrialization of the new technologies, which is the main goal of the work, requires predictable conditions within several areas of the industry, and in this regard the authorities have a great influence. Availability and prices of operational inputs such as electricity and raw materials, as well as suitable infrastructure, fall under these conditions. Investment in new technologies is often hindered by lack of risk capital. Measures to increase the availability of risk capital and decrease the risk taken by the industrial companies are means to enhance introduction of new technologies.

As illustrated, a roadmap is a tool to inform role-players about the possibilities and requirements needed to reach specific objectives. A similar approach and roadmap could pave the way towards increased manganese ferroalloy production in South Africa.

\section{Conclusions}

To increase the production of manganese ferroalloys in South Africa, a research agenda was developed at a workshop hosted as part of the Second School on Manganese Ferroalloy Production in June 2016. The agenda consists of 21 research themes distilled from 95 research opportunities identified by participants in the workshop. The literature review that was conducted subsequent to the workshop indicated that the problems identified are not unique to the South African context. In particular, challenges associated with high prices of electricity and raw materials, as well the need for higher yields and a stronger market for alloys, are also experienced elsewhere in the world. Many of the ideas generated at the workshop were not new as they have been addressed in the past, even on an industrial scale, locally or in other parts of the world. To implement the agenda, collaborative research between industry and research institutions and between institutions locally and overseas would be required. Studies should focus on the South African context: challenges with the supply of raw materials and energy as well as the need to develop human capital, and should evaluate both the technical and the economic feasibility of solutions proposed. A technology roadmap is a useful tool for directing such a collaborative research exercise, and the development of such a roadmap by industry and research institutions is strongly encouraged. Implementation the roadmap will require support from the authorities.

\section{Acknowledgements}

This paper is published with the financial support and permission of Mintek. Inputs from delegates participating in the workshop at the 2nd School on Manganese Ferro-alloy Production are gratefully acknowledged.

\section{References}

Alex, T.C., Godiwalla, K.M., Kumar, S., and Jana, R.K. 2007. Extraction of silicomanganese from marine and low grade mineral resources. Proceedings of INFACON XI, New Delhi, India, 18-21 February 2007. Indian Ferro-Alloy Producers Association. pp. 206-214.

Anacleto, N., Ostrovski, O., and GAnguly, S. 2004. Reduction of manganese oxides by methane-containing gas. ISIJ International, vol. 44, no. 9. pp. $1480-1487$

BANDA, W. and LAGENDIJK, H. 2017a. Metallothermic production of cement extender from manganese waste slags. Proceedings of the 3rd Young Professionals Conference, Pretoria, South Africa, 9-10 March 2017. Southern African Institute of Mining and Metallurgy, Johannesburg. pp. 331-334.

BANDA, W. AND LAGENDIK, H. 2017b. Metallothermic production of cement extender from manganese waste slags. Proceedings of the 5 th International Slag Valorisation Symposium, Leuven, Belgium, 3-5 April 2017. KU Leuven.

BASSON, J., CURR, T.R., and Gericke, W.A. 2007. South Africa's ferro alloys industry - present status and future outlook. Proceedings of INFACON XI, New Delhi, India, 18-21 February 2007. Indian Ferro-Alloy Producers Association. pp. 3-24.

BEZEMER, K. 1995. The silicomanganese production process at Transalloys Proceedings of INFACON VII. Trondheim, Norway, 11-14 June 1995. Tveit, H., Tuset, J.K., and Page, I.G. (eds.). Norwegian Ferroalloy Producers Research Organization (FFF). pp. 573-580.

BHALLA, A. and ERIC, R.H. 2015. Reduction behavior of manganese ore using methane gas. Proceedings of INFACON XIV, Kiev, Ukraine, 1-4 June 2015 pp. 461-469.

BHonde, P.J. and AngAL, R.D. 2004. Rate control mechanism in solid state decarburization of ferromanganese. Proceedings of INFACON X, Cape Town, South Africa, 1-4 February 2004. Southern African Institute of Mining and Metallurgy, Johannesburg. pp. 163-172.

BISAKA, K., GRIESEL, J., and BouwER, P.H.F. 2004. Optimisation of SiMn production at Transalloys. Proceedings of INFACON X, Cape Town, South Africa, 1-4 February 2004. Southern African Institute of Mining and Metallurgy, Johannesburg. pp. 239-244.

BuRgER, R. and MASUKAWA, M. 2004. The production of refined ferromanganese at Cato Ridge alloys. Proceedings of INFACON X, Cape Town, South Africa, 1-4 February 2004. Southern African Institute of Mining and Metallurgy, Johannesburg. pp. 254-260.

Channon, W.P. and SEE, J.B. 1977. The reduction of fluxed and non-fluxed manganese ores by ferromanganese silicide. Staff paper no. 1868. Mintek, Johannesburg, South Africa.

Chaudhary, P.N., Minj, R.K., and Goel, R.P. 2007. Development of a process for dephosphorisation of high carbon manganese. Proceedings of INFACON $X I$, New Delhi, India, 18-21 February 2007. Indian Ferro-Alloy Producers Association. pp. 289-296.

CHETTY, D. 2008. A geometallurgical evaluation of the ores of the northern Kalahari manganese deposit, South Africa. PhD thesis, University of Johannesburg, Johannesburg, South Africa.

Chetty, D. and Gutzmer, J. 2008. Quantitative X-ray diffraction as a tool for smelting optimization of Kalahari manganese ores. Proceedings of the Ninth International Congress for Applied Mineralogy. Brisbane, Australia, 8-10 September 2008. pp. 419-427.

CHu, S.J., Chen, P.X., and Zeng, S.L. 2015. Research on de-titanium of silicomanganese ferroalloy by blowing N2. Proceedings of INFACON XIV, Kiev, Ukraine, 1-4 June 2015. pp. 497-504.

Coetsee, T., Muller, J., Groenewald, J., du Toit, A., and Zeelie, D. 2015. The AlloyStream process for HCFeMn production. Proceedings of INFACON XIV, Kiev, Ukraine, 1-4 June 2015. pp. 91-98.

Cowx, P., Nordhagen, R., Kadkhodabeigi, M., Els, L., and Kero, I. 2015. The use of fine water spray to suppress fume emissions when casting refined ferromanganese. Proceedings of INFACON XIV, Kiev, Ukraine, 1-4 June 2015. pp. 81-90.

CORATHERS, L.A. 2017. Mineral commodity summaries 2017. U.S. Geological Survey. pp. 106-107.

Crawford, D.P., Mayjeed, P.L.J., Bren, A.D., and Olsen, A.H. 1995. Direct production of ferromanganese from Gemco sand concentrate and coal. Proceedings of INFACON VII, Trondheim, Norway, 11-14 June 1995. Tveit, H., Tuset, J.K., and Page, I.G. (eds.). Norwegian Ferroalloy Producers Research Organization (FFF). pp. 239-248. 


\section{Working towards an increase in manganese ferroalloy production in South Africa}

Dalaker, H., Ringdalen, E., Kolbeinsen, L., and Mårdalen, J. 2017. Road-map for gas in the Norwegian metallurgical industry: greater value creation and reduced emissions. SINTEF, Trondheim, Norway.

Dashevskiy, V.Y., Aleksandrov, A.A., KanevskiY, A.G., and Leontiev, L.I. 2013. Extraction of manganese from the slag of silicothermal reduction of metallic manganese. Proceedings of INFACON XIII, Almaty, Kazakhstan, 9-12 June 2013. pp. 157-164.

DAveY, K. 2004. The develpment of an agglomerate through the use of FeMn waste. Proceedings of INFACON $X$, the Tenth International Ferroalloys Congress, Cape Town, South Africa, 1-4 February 2004. Southern African Institute of Mining and Metallurgy, Johannesburg. pp. 272-280.

Directorate: Mineral Economics. 2016. South Africa's Mineral Industry 2014/2015. Department of Mineral Resources, Pretoria, South Africa, p. 128.

EIDEM, P.A., EGELAND, K.A., and BaumanN, D. 2013. Improved safety for manganese alloy smelting. Efficient Technologies in Ferroalloy Industry: Proceedings of INFACON XIII, Almaty, Kazakhstan, 9-12 June 2013 pp. 164-174.

FEATHERSTONE, R.A. 1974. Applications of Mamatwan manganese ore. Proceedings of INFACON I, Johannesburg, South Africa, 22-26 April 1974 Southern African Institute of Mining and Metallurgy, Johannesburg. pp. 263-271.

GAal, S., TANGSTAD, M., and RAvARY, B. 2010. Recycling of waste material from the production of FeMn and SiMn. Proceedings of INFACON XII, Helsinki, Finland, 6-9 June 2010. Outotec Oyj. pp. 81-88.

GerefFi, G. and Fernandez-Stark, K. 2011. Global Value Chain Analysis: A Primer. Center on Globalization, Governance $\&$ Competitiveness.

GHALI, N.S., EISSA, M.M., MishreKY, M.L., and El-FAWAKHRY, M.K. 2010. Kinetics of nitriding process of ferromanganese alloy. Proceedings of INFACON XII, Helsinki, Finland, 6-9 June 2010. pp. 611-618.

GHORPADE, S.Y. 1995. Strategic plan to abate pollution and beneficiate low grade manganese ore at Simiore's metal and ferroalloys plant. Proceedings of INFACON VII, Trondheim, Norway, 11-14 June 1995. Tveit, H., Tuset, J.K., and Page, I.G. (eds.). Norwegian Ferroalloy Producers Research Organization (FFF). pp. 151-164.

Grishchenko, S.G., Ovcharuk, A.N., Olshansky, V.I., Filippov, I.Y., TARan, A.Y., CHALENKo, V.I., DuDYAK, V.N., and PAVLENKo, S.V. 2015. Mastering of ferrosilicon manganese melting with highly reactive reducing agent. Proceedings of INFACON XIV, Kiev, Ukraine, 1-4 June 2015. pp. 65-72.

Groot, D.R., Kazadi, D., Pöllmann, H., De Villiers, J.P.R., Redtmann, T., and STEENKAMP, J.D. 2013. The recovery of manganese and generation of a valuable residue from ferromanganese slags by a hydrometallurgical route. Proceedings of INFACON XIII, Almaty, Kazakhstan, 9-12 June 2013. pp. 1051-1060.

Hamano, T., Shen, R., Zhang, G., Brown, P., and Ostrovski, O. 2010. Process of manganese furnace dust: drying and zinc oxide reduction. Proceedings of INFACON XII, Helsinki, Finland, 6-9 June 2010. pp. 143-154

HockADAY, S.A.C., DinTER, F., and HARMS, T.M. 2016. Opportunities for concentrated solar thermal heat in the minerals processing industry. 4th Southern African Solar Energy Conference (SASEC) 2016, Stellenbosch University in Stellenbosch, South Africa, 31 October - 2 November 2016

Hockaday, S.A.C., REynoldS, Q.G., DinTer, F., and HaRms, T.M. 2017. Solar thermal treatment of manganese ores. ProceedingS of SolarPACES 2017, Santiago, Chile, 26-29 September 2017.

Hunsbedt, L., Cowx, P.M., Flatabø, R., Johansen, K.E., and Bustnes, J.A. 2007. Environmental challenges for Norwegian Mn- Industry. Proceedings of INFACON XI, New Delhi, India, 18-21 February 2007. Indian Ferro-Alloy Producers Association. pp. 446-456.

JABAREEN, Y. 2008. A new conceptual framework for sustainable development. Journal of Environment, Development and Sustainability, vol. 10. pp. $179-192$

InHUA, Z. and ZHIZHong, L. 1992. The development of technology for the production of refined ferromanganese in China. ProceedingS of INFACON VI, Cape Town, South Africa, 8-11 March 1992. Southern African Institute of Mining and Metallurgy, Johannesburg. pp. 145-147.

Jones, R.T., BARCZA, N.A., and CuRR, T.R. 1993. Plasma Developments in Africa. Proceedings of the Second International Plasma Symposium: World Progress In Plasma Applications, Palo Alto, California, 9-11 February 1993.

Kalenga, M., Xiaowei, P., and TAngstad, M. 2013. Manganese alloys production: Impact of chemical compositions of raw materials on the energy and materials balance. Proceedings of INFACON XIII, Almaty, Kazakhstan, 9-12 June 2013. pp. 647-654.
Kamata, R., Kuzi, Y., and Tsuimura, H. 1992. The production of special SiMn using the gas and powder injection process. Proceedings of INFACON VI, Cape Town, South Africa, 8-11 March 1992. Southern African Institute of Mining and Metallurgy, Johannesburg. pp. 139-143.

Kazadi, D., Groot, D.R., Pöllmann, H., DE Villiers, J.P.R., and Redtmann, T. 2013. Utilization of ferromanganese slags for manganese extraction and as cement additive. Proceedings of the International Conference on Advances in Cement and Concrete Technology in Africa, Johannesburg, South Africa, 28-30 January 2013. pp. 983-995.

Kazadi, D.M., Groot, D.R., DE Villiers, J.P.R., Steenkamp, J.D., and Pöllmann, H. 2016. Control of silica polymerisation during ferromanganese slag sulfuric acid digestion and water leaching. Hydrometallurgy, vol. 166. pp. 214-221.

KitAMURA, M. 1983. Improvement of the electric power consumption in silicomanganese smelting. Proceedings of INFACON III, Tokyo, Japan, 8-11 May 1983.

Kivinen, V., Krogerus, H., and DaAvitTiLA, J. 2010. Upgrading of Mn/Fe ratio of low-grade manganese ore for ferromanganese production. Proceedings of INFACON XII, Helsinki, Finland, 6-9 June 2010. pp. 467-476.

Kononov, R., Ostrovski, O., and Ganguly, S. 2007. Carbothermal solid state reduction of manganese ores. Proceedings of INFACON XI, New Delhi, India, 18-21 February 2007. Indian Ferro-Alloy Producers Association. pp. 259-267.

Kumar, M., Ranganathan, S., and Sinha, S.N. 2007. Kinetics of reduction of different manganese ores. Proceedings of INFACON XI, New Delhi, India, 18-21 February 2007. Indian Ferro-Alloy Producers Association. pp. 241-246.

Kutsin, V.S., Olshansky, V.I., FILIPPov, I.Y., and Chumakov, A.A. 2015. The development of fine manganese concentrate lumping technology at PJSC Nikopol Ferroalloy Plant. Proceedings of INFACON XIV, Kiev, Ukraine, 1-4 June 2015. pp. 22-26.

LeE, K.J., Min, D.S., PARK, C.S., PARK, Y.K., Jo, C.H., and Hong, S.H. 2010. High purity Mn metal from Mn oxide dust produced during FeMn refining process. Proceedings of INFACON XII, Helsinki, Finland, 6-9 June 2010. pp. 197-206.

LEE, Y.E. and TANGSTAD, M. 2010. Electric parameters for an efficient smelting perfomance of HCFeMn alloy. Proceedings of INFACON XII, Helsinki, Finland, 6-9 June 2010. pp. 569-578.

Malan, J., BARThel, W., and DipPenAar, B.A. 2004. Optimising manganese sinter plants process parameters and design. Proceedings of INFACON $X$ Cape Town, South Africa, 1-4 February 2004. Southern African Institute of Mining and Metallurgy, Johannesburg. pp. 281-290.

Maroufi, S., Ciezki, G., Jahanshahi, S., Sun, S., and Ostrovski, O. 2015 Dissolution of silica in slag in silicomanganese production. Proceedings of INFACON XIV, Kiev, Ukraine, 1-4 June 2015. pp. 479-487.

MiYauchi, Y., MochiDA, M., and Fuchi, Y. 2001. High thermal electrical property of manganese ore in production of high carbon ferromanganese. Proceedings of INFACON IX, Quebec City, Canada, 3-6 June 2001. The Ferroalloys Association, Washington. pp. 263-243.

Miyauchi, Y., Nishi, T., SAito, K., and Kizu, Y. 2004. Improvement of hightemperature electric characteristics of manganese ores. Proceedings of INFACON X, Cape Town, South Africa, 1-4 February 2004. Southern African Institute of Mining and Metallurgy, Johannesburg. pp. 155-162.

Monsen, B., TAngstad, M., and MidtgaAr, H. 2004. Use of charcoal in silicomanganese production. Proceedings of INFACON X, Cape Town, South Africa, 1-4 February 2004. Southern African Institute of Mining and Metallurgy, Johannesburg. pp. 392-404.

Monsen, B., Tangstad, M., Syvertsen, M., IshaK, R., and MidtgaArd, H. 2007. Charcoal for manganese alloy production. Innovations in Ferro Alloy Industry. Proceedings of INFACON XI, New Delhi, India, 18-21 February 2007. Indian Ferro-Alloy Producers Association. pp. 297-310.

NeLL, J. and NolET, I. 2010. Development of a dynamic model for a manganese oxygen refining (MOR) converter. ProceedingS of INFACON XII, Helsinki, Finland, 6-9 June 2010. pp. 579-588.

Nishi, T., SAitoh, K., and Teguri, D. 2007. The build-up of additional HCFeMn production capacity by the deepening of a furnace. Proceedings of INFACON XI, New Delhi, India, 18-21 February 2007. Indian Ferro-Alloy Producers Association. pp. 183-190.

NoRSK INDUSTRI. 2006. The Norwegian process industries' roadmap: combining growth and zero emissions by 2050 . 


\section{Working towards an increase in manganese ferroalloy production in South Africa}

Olsen, S.E., TAngstad, M., and Lindstad, T. 2007. Production of Manganese Ferroalloys. Tapir Academic Press, Trondheim, Norway.

O'Shaughnessy, P. and LE Roux, F. 2015. Evaluation of furnace refractory linings after sixteen years of producing silicomanganese. Proceedings of INFACON XIV, Kiev, Ukraine, 1-4 June 2015. pp. 278-299.

Ostrovski, O., Anacleto, N., and Ganguly, S. 2004. Reduction of manganese ores by methane containing gas. Transformation through Technology. Proceedings of INFACON X, Cape Town, South Africa, 1-4 February 2004. Southern African Institute of Mining and Metallurgy, Johannesburg. pp. 173-183.

Osypenko, V.V., Osypenko, V.D., ShuvAYev, S.P., and KoRKodola, I.I. 2015. Development and introduction of an innovative technology of exhaust gas purification for manufacture of manganese agglomerate. Proceedings of INFACON XIV, Kiev, Ukraine. 1-4 June 2015, pp. 724-732.

Park, J.H., PARK, G.H., PARK, C.I., Min, D.J., Jo, C.H., and LeE, Y.E. 2010. Thermodynamics of carbon removal by molten slags from manganese alloy melts. Proceedings of INFACON XII, Helsinki, Finland. pp. 601-610.

PhaAl, R., FArrukh, C.J.P., and Probert, D.R. 2004. Technology roadmapping A planning framework for evolution and revolution. Technological Forecasting and Social Change, vol. 71, Issue 1-2, pp. 5-26.

PIENAAR, P.C. and SMITH, W.F.P. 1992. A case study of the production of highgrade manganese sinter from low-grade Mamatwan manganese ore. Proceedings of INFACON VI, Cape Town, South Africa, 8-11 March 1992. Southern African Institute of Mining and Metallurgy, Johannesburg. pp. 131-138.

PISTORIUs, P.C. 2002. Reductant selection in ferro-alloy production: The case for the importance of dissolution in the metal. Journal of the Southern African Institute Mining and Metallurgy, vol. 102, no. 1. pp.33-36.

Pochart, G., Joncourt, L., Touchard, N., and Perdon, C. 2007. Metallurgical benefit of reactive high grade ore in manganese alloys manufacturing. Proceedings of INFACON XI, New Delhi, India, 18-21 February 2007. Indian Ferro-Alloy Producers Association. pp. 217-230.

REINDERS, L. 2016. Conserving functionality of relatively rare metals associated with steel life cycles: a review. Journal of Cleaner Production, vol. 131. pp. 76-96.

Ringdalen, E., GaAL, S., and Ostrovski, O. 2010. Ore properties in melting and reductions in silicomanganese production. Proceedings of INFACON XII, Helsinki, Finland. pp. 487-496.

SAdRi, A., Gebski, P., and Shameli, E. 2010. Refractory wear and lining profile determination in operating electric furnaces using stress wave nondestructive testing (NDT). Proceedings of INFACON XII, Helsinki, Finland. pp. 881-890.

Safarian, J., Grong, Ø., Kolbeinsen, L., and Olsen, S.E. 2006. A process model for the carbothermic reduction of $\mathrm{MnO}$ from high carbon ferromanganese slag - The model. ISIJ International, vol. 46. pp. 1120-1129.

SAfARIAn, J. and KolBEINSEn, L. 2013. Purity requirements for Mn-alloys for producing high manganese TRIP and TWIP steels. Proceedings of INFACON XIII, Almaty, Kazakhstan, 9-12 June 2013. pp. 175-184.

Safarian, J. and Kolbeinsen, L. 2008. Kinetic of carbothermic reduction of mno from high-carbon ferromanganese slag by graphite materials. ISIJ International, vol. 48. pp. 395-404.

Safarian, J., Tranell, G., Kolbeinsen, L., Tangstad, M., GaAl, S., and KaczonowsKi, J. 2008. Reduction kinetics of Mno from high-carbon ferromanganese slags by carbonaceous materials in Ar and CO atmospheres. Metallurgical and Materials Transactions B, vol. 39. pp. 702-712.

Samuratov, Y., Baisanov, A., and Tolymbeкov, M. 2010. Complex processing of iron-manganese ore of central Kazakhstan. Proceedings of INFACON XII, Helsinki, Finland. pp. 517-520.

Sancho, J., Recio, J.C., Fuentes, A., Ayala, J., Bernardo, J.L., and Rodríguez, C. 2015. Electrolytic manganese from ferroalloy production furnace flying dust. Proceedings of INFACON XIV, Kiev, Ukraine, 1-4 June 2015. pp. 759-762.

SARIDiKMen, H., KucukKaragoz, C.S., and ERIC, R.H. 2007. Sulphur behaviour in ferromanganese smelting. Innovations in Ferro Alloy Industry. Proceedings of INFACON XI, New Delhi, India, 18-21 February 2007. Indian Ferro-Alloy Producers Association. pp. 312-320.

SitHole, N.A., BAm, W.G., and StEenKAMP, J.D. 2018. Comparing electrical and carbon combustion based energy technologies for the production of high carbon ferromanganese: A literature review. Proceedings of INFACON XV Cape Town, South Africa, 25-28 February 2018. Southern African Institute of Mining and Metallurgy, Johannesburg.

Sjoevist, T., Jonsson, P., and Berg, H. 2001. The effect of ferro manganese cleanness on inclusions in steel. Proceedings of INFACON IX, Quebec City, Canada, 3-6 June 2001. pp. 411-420.

StATs SA. 2015. Labour market dynamics in South Africa. Statistics South Africa, Pretoria, South Africa. p. 3

StEENKAMP, J.D. 2014. Chemical wear of carbon-based refractory materials in a silicomanganese furnace tap-hole. $\mathrm{PhD}$ thesis, University of Pretoria, Pretoria, South Africa.

StEENKAMP, J.D. and BASson, J. 2013. The manganese ferroalloys industry in southern Africa. Journal of the Southern African Institute of Mining and Metallurgy, vol. 113. pp. 667-676.

SteenkAmp, J.D., Pistorius, P.C., and TAngSTAD, M. 2015a. Wear mechanisms of carbon-based refractory materials in silicomanganese tap-holes - Part 1: equilibrium calculations and slag and refractory characterisation. Metallurgical and Material Transactions B, vol. 46B. pp. 653-667.

SteEnkAmp, J.D., Pistorius, P.C., and TANGSTAD, M. 2015b. Wear mechanisms of carbon-based refractory materials in SiMn tap-holes - Part 2: In-situ observation of chemical reactions. Metallurgical and Material Transactions B, vol. 46B. pp. 668-679.

SteEnKAMP, J.D., PISTORIUS, P.C., and TANGSTAD, M. 2015c. Chemical wear analysis of a tap-hole on a SiMn production furnace. Journal of the Southern African Institute of Mining and Metallurgy, vol. 115. pp. 199-208.

SuZUKI, S. and MASUKAWA, M. 1992. High-productivity operation of a shaft-type ferromanganese smelting furnace. Proceedings of INFACON VI, Cape Town, South Africa, 8-11 March 1992. Southern African Institute of Mining and Metallurgy, Johannesburg. pp. 149-154.

Swamy, K.N., Robertson, D.G.C., CAlvert, P., and KozaK, D. 2001. Factors affecting carbon consumption in the production of high carbon ferromanganese. Proceedings of INFACON IX, Quebec City, Canada, 3-6 June 2001. pp. 293-301.

Tangstad, M., Calvert, P., Brun, H., and Lindseth, A.G. 2004. Use of Comilog ore in ferromanganese production. Proceedings of INFACON X, Cape Town, South Africa, 1-4 February 2004. Southern African Institute of Mining and Metallurgy, Johannesburg. pp. 213-222.

TAngstad, M., IchiHARa, K., and Ringdalen, E. 2015. Pretreatment unit in ferromanganese production. Proceedings of INFACON XIV, Kiev, Ukraine 1-4 June 2015. pp. 99-106.

TAngstad, M., Sibony, M., Wasbo, S., and Tronstad, R. 2001. Kinetics of the prereduction of manganese ores. Proceedings of INFACON IX, Quebec City, Canada, 3-6 June 2001. pp. 202-207.

VAN ZyL, H.J. 2017. Identifying barriers to growth in mineral value chains: an analytical framework approach. Master's dissertation, University of Stellenbosch, Stellenbosch, South Africa.

VAN ZyL, H.J., BAM, W.G., and StEENKAMP, J.D. 2016. Identifying barriers faced by key role players in the South African manganese industry. Proceedings of the 27th SAIIE Annual Conference, Stonehenge in Africa, North West Province, South Africa, 27-29 October 2016.

Visser, M., Smith, H., Ringdalen, E., and TAngstad, M. 2013. Properties of Nchwaning and Gloria ore in the production of Mn ferroalloys. Proceedings of INFACON XII, Helsinki, Finland, 6-9 June 2010. pp. 553-566.

YAmamoto, K., Ito, S., Terada, S., Soejima, T., and Kurita, Y. 1986. Improvement of energy efficiency by process computer for ferroalloy electric furnace, and production of medium or low carbon ferromanganese by direct decarbonization of FMnH melt. Proceedings of INFACON IV, Rio de Janeiro, Brazil, 31 August - 3 September, 1986. Associação Brasileira dos Produtores de Ferro-Ligas-Abrafe pp. 63-78.

ZHANG, T. 1992. The two-stage production of high-carbon ferromanganese in a blast furnace: A method for the treatment of a lean manganese ore. Proceedings of INFACON VI, Cape Town, South Africa, 8-11 March 1992. Southern African Institute of Mining and Metallurgy, Johannesburg. pp. 155-159.

ZHAO, Y., ZHu, G., and CHENG, Z. 2010. Thermal analysis and kinetic modeling of manganese oxide ore reduction using biomass straw as reductant. Hydrometallurgy, vol. 105. pp. 96-102. 